\title{
Kajian Respon Bangunan Menggunakan Base Isolator pada Gedung Bertingkat Sistem Pracetak dan Sistem Cast in Situ
}

\author{
ARDIANSYAH IBRAHIM, ERMA DESMALIANA, \\ AMATULHAY PRIBADI
}

\author{
Jurusan Teknik Sipil, Institut Teknologi Nasional, Bandung \\ Email:ardiansyahibrahim4@gmail.com
}

\begin{abstract}
ABSTRAK
Indonesia merupakan wilayah yang memiliki resiko gempa yang cukup tinggi karena terletak pada pertemuan tiga lempeng tektonik,oleh karena itu telah dikembangkan metode desain alternatif dengan tujuan untuk mengurangi resiko kerusakan bangunan akibat beban gempa yang dikenal dengan nama sistem isolasi gempa (seismic isolation). Pada bangunan ini dipasang base isolator jenis High Damping Rubber Bearing (HDRB) dengan diameter $600 \mathrm{~mm}$ dan tinggi 407,9 mm.Berdasarkan hasil, diperoleh bahwa penggunaan base isolator dapat memperpanjang periode struktur bangunan dua kali untuk kedua sistem, kemudian dapat mereduksi gaya geser arah X mencapai 40\% dan arah $Y$ mencapai 50\% untuk kedua sistem, lalu memperkecil simpangan antar lantai dan juga membutuhkan waktu yang lebih singkat untuk mencapai faktor partisipasi modal yang diinginkan sesuai peraturan yaitu minimal 90\%. Kesimpulan dari penelitian ini adalah struktur bangunan beton pracetak lebih efektif dibandingkan dengan beton cast in situ dari aspek respon struktur.
\end{abstract}

Kata kunci: pracetak, cast in situ, high damping rubber bearing

\begin{abstract}
Indonesia is prone to seismic hazard load due to its location situated on a meeting point of three tectonic plates, therefore the alternative design methods have been developed with the aim to reduce the risk of damage to buildings due to the load known as the earthquake isolation system. At one of the building analyzed in this research was provided with High Damping Rubber Bearing (HDRB) with a diameter of $600 \mathrm{~mm}$ and a height of 407,9 mm. Based on the results obtained, the use of base isolator can extend the period of the structure of the building twice forboth systems, reduce the shear force reached $40 \%$ in the $X$ direction and $50 \%$ in the $Y$ direction for both systems, and then minimize the deviation between floors of a building and also requires less time to achieve the desired modal participation factors according the regulations that is at least $90 \%$. The conclusion of this research is that the structure of precast concrete is more effective than cast in situ concrete from the aspect of structure response.
\end{abstract}

Keywords: precast, cast in situ, high damping rubber bearing 


\section{PENDAhUlUAN}

Wilayah Indonesia merupakan negara yang rawan terjadi gempa bumi. Tingginya potensi gempa bumi disebabkan letak geografis Indonesia yang berada pada pertemuan tiga lempeng tektonik utama. Perencanaan gedung yang sudah menganut kaidah yang ada tetap masih menghasilkan interstory drift yang tinggi. Untuk memperkecil interstory drfit adalah dengan meredam energy gempa yang terjadi sampai pada tingkat yang tidak membahayakan bangunan.

Dewasa ini telah dikembangkan metode desain alternatif dengan tujuan untuk mengurangi resiko kerusakan bangunan akibat beban gempa. Metode ini dikenal dengan nama sistem isolasi gempa (seismic isolation). Sistem ini biasanya diterapkan pada bangunan bertingkat yang rentan terhadap beban gempa, dengan menambahkan base isolator pada bagian bawah struktur bangunan. Berdasarkan latar belakang tersebut, maka akan dilakukan penelitian mengenai bagaimana perbandingan respons struktur dalam penggunaan base isolator pada gedung bertingkat sistem pracetak dan sistem cast in situ.

\section{TINJAUAN PUSTAKA}

\subsection{Prinsip Sistem Base Isolation}

Prinsip dari base isolation pertama kali dikemukakan oleh J. A. Calantarients tahun (1990) dalam Naeim, F., \& Kelly, J.M., (1999). Calantarients berpendapat bahwa gempa yang mengenai bangunan dapat direduksi dengan memasang free joint diantara struktur atas dan bawah sehingga bangunan dapat bergerak horizontal pada free joint tersebut.

\subsection{Beton Pracetak}

Beton pracetak dapat diartikan sebagai suatu proses produksi elemen struktur bangunan pada suatu tempat atau lokasi yang berbeda dengan lokasi dimana elemen struktur tersebut akan digunakan. Teknologi pracetak ini dapat diterapkan pada berbagai jenis material, yang salah satunya adalah material beton.

\subsection{Beton Cast in Situ}

Beton cast in situ adalah suatu komponen struktur yang paling utama dalam sebuah bangunan. Beton cast in situ dalam pembuatannya direncanakan terlebih dahulu, semua pekerjaan pembetonan dilakukan secara manual dengan merangkai tulangan pada bangunan yang dibuat. Pembetonan cast in situ memerlukan biaya bekisting dan biaya upah pekerja yang cukup banyak.

\subsection{Jenis-jenis Isolasi Dasar (Base Isolation)}

Berdasarkan dari bahan pembuatannya, isolasi dasar dapat dibagi menjadi dua macam, yaitu isolasi dasar yang menggunakan bahan karet sebagai isolator (rubber type) dan yang menggunakan material selain karet sebagai isolatornya (nonrubber type).

\subsection{Perletakan Isolasi Dasar}

Perletakan isolasi dasar sebaiknya serendah mungkin agar dapat melindungi struktur sebanyak mungkin. Pertimbangan biaya dan praktis juga mempengaruhi pemilihan lokasi perletakan isolator dasar ini. Pada bangunan, pemilihan perletakan lebih baik terletak pada lantai dasar (ground level) di bawah basement (Myes, R. L. \& Naeim, F., 2001). 


\subsection{Peraturan yang Digunakan}

Peraturan yang digunakan dalam penelitian ini adalah SNI 1726-2012 tentang Tata Cara Perencanaan Ketahanan Gempa untuk Struktur Bangunan Gedung dan Non Gedung serta SNI 1727-2013 tentang Pembebanan Minimum untuk Perencanaan Bangunan Gedung dan Struktur Lain.

\subsection{Pembebanan}

Pembebanan dalam penelitian ini menggunakan peraturan SNI 1727-2013 dengan beban yang bekerja pada struktur adalah beban mati (DL), beban hidup (LL), beban mati tambahan $(\mathrm{SiDL})$, beban gempa $\left(\mathrm{EQ}_{\mathrm{x}}\right.$ dan $\left.\mathrm{EQ}_{\mathrm{y}}\right)$, dan beban atap $(\mathrm{R})$.

\subsection{Kombinasi Pembebanan}

Kombinasi pembebanan dalam penelitian ini mengacu pada SNI 1726-2012 tentang Tata Cara Perencanaan Ketahanan Gempa untuk Struktur Bangunan Gedung dan Non Gedung. Kombinasi pembebanan dapat dilihat pada Tabel 1.

Tabel 1. Kombinasi Pembebanan

\begin{tabular}{|c|c|}
\hline No & Kombinasi Pembebanan \\
\hline 1 & $1,4 \mathrm{DL}+1,4 \mathrm{SiDL}$ \\
\hline 2 & $1,2 \mathrm{DL}+1,2 \mathrm{SiDL}+1,6 \mathrm{LL}+0.5 \mathrm{R}$ \\
\hline 3 & $1,2 \mathrm{DL}+1,2 \mathrm{SiDL}+1 \mathrm{LL}+1,6 \mathrm{R}$ \\
\hline 4 & $\left(1,2+1,2 \mathrm{~S}_{\mathrm{DS}}\right) \mathrm{DL}+\left(1,2+1,2 \mathrm{~S}_{\mathrm{DS}}\right) \mathrm{SiDL}+1 \mathrm{LL}+(0,3 \rho) \mathrm{Eq}_{\mathrm{x}}+(1 \rho) \mathrm{Eq}_{\mathrm{y}}$ \\
\hline 5 & $\left(1,2+1,2 S_{D S}\right) \mathrm{DL}+\left(1,2+1,2 \mathrm{~S}_{\mathrm{DS}}\right) \mathrm{SiDL}+1 \mathrm{LL}+(0,3 \rho) \mathrm{Eq}_{\mathrm{x}}-(1 \rho) \mathrm{Eq}_{\mathrm{y}}$ \\
\hline 6 & $\left(1,2+1,2 S_{D S}\right) D L+\left(1,2+1,2 S_{D S}\right) S i D L+1 L L-(0,3 \rho) E_{x}+(1 \rho) \mathrm{Eq}_{y}$ \\
\hline 7 & $\left(1,2+1,2 \mathrm{~S}_{\mathrm{DS}}\right) \mathrm{DL}+\left(1,2+1,2 \mathrm{~S}_{\mathrm{DS}}\right) \mathrm{SiDL}+1 \mathrm{LL}-(0,3 \rho) \mathrm{Eq}_{\mathrm{x}}-(1 \rho) \mathrm{Eq}_{\mathrm{y}}$ \\
\hline 8 & $\left(1,2+1,2 \mathrm{~S}_{\mathrm{DS}}\right) \mathrm{DL}+\left(1,2+1,2 \mathrm{~S}_{\mathrm{DS}}\right) \mathrm{SiDL}+1 \mathrm{LL}+(1 \rho) \mathrm{Eq}_{\mathrm{x}}+(0,3 \rho) \mathrm{Eq}_{\mathrm{y}}$ \\
\hline 9 & $\left(1,2+1,2 \mathrm{~S}_{\mathrm{DS}}\right) \mathrm{DL}+\left(1,2+1,2 \mathrm{~S}_{\mathrm{DS}}\right) \mathrm{SiDL}+1 \mathrm{LL}+(1 \rho) \mathrm{Eq}_{\mathrm{x}}-(0,3 \rho) \mathrm{Eq}_{\mathrm{y}}$ \\
\hline 10 & $\left(1,2+1,2 S_{D S}\right) D L+\left(1,2+1,2 S_{D S}\right) S i D L+1 L L-(1 \rho) E_{x}+(0,3 \rho) E_{y}$ \\
\hline 11 & $\left(1,2+1,2 \mathrm{~S}_{\mathrm{DS}}\right) \mathrm{DL}+\left(1,2+1,2 \mathrm{~S}_{\mathrm{DS}}\right) \mathrm{SiDL}+1 \mathrm{LL}-(1 \rho) \mathrm{Eq}_{\mathrm{x}}-(0,3 \rho) \mathrm{Eq}_{\mathrm{y}}$ \\
\hline 12 & $\left(1,2+1,2 \mathrm{~S}_{\mathrm{DS}}\right) \mathrm{DL}+\left(1,2+1,2 \mathrm{~S}_{\mathrm{DS}}\right) \mathrm{SiDL}+(0,3 \rho) \mathrm{Eq}_{x}+(1 \rho) \mathrm{Eq}_{\mathrm{y}}$ \\
\hline 13 & $\left(1,2+1,2 \mathrm{~S}_{\mathrm{DS}}\right) \mathrm{DL}+\left(1,2+1,2 \mathrm{~S}_{\mathrm{DS}}\right) \mathrm{SiDL}+(0,3 \rho) \mathrm{Eq}_{\mathrm{x}}-(1 \rho) \mathrm{Eq}_{\mathrm{y}}$ \\
\hline 14 & $\left(1,2+1,2 S_{D S}\right) \mathrm{DL}+\left(1,2+1,2 S_{D S}\right) \operatorname{SiDL}-(0,3 \rho) \mathrm{Eq}_{x}+(1 \rho) \mathrm{Eq}_{y}$ \\
\hline 15 & $\left(1,2+1,2 \mathrm{~S}_{D S}\right) \mathrm{DL}+\left(1,2+1,2 \mathrm{~S}_{\mathrm{DS}}\right) \mathrm{SiDL}-(0,3 \rho) \mathrm{Eq}_{\mathrm{x}}-(1 \rho) \mathrm{Eq}_{\mathrm{y}}$ \\
\hline 16 & $\left(1,2+1,2 \mathrm{~S}_{\mathrm{DS}}\right) \mathrm{DL}+\left(1,2+1,2 \mathrm{~S}_{\mathrm{DS}}\right) \mathrm{SiDL}+(1 \rho) \mathrm{Eq}_{\mathrm{x}}+(0,3 \rho) \mathrm{Eq}_{\mathrm{y}}$ \\
\hline 17 & $\left(1,2+1,2 S_{D S}\right) \mathrm{DL}+\left(1,2+1,2 S_{D S}\right) \mathrm{SiDL}+(1 \rho) \mathrm{Eq}_{x}-(0,3 \rho) \mathrm{Eq}_{\mathrm{y}}$ \\
\hline 18 & $\left(1,2+1,2 S_{D S}\right) \mathrm{DL}+\left(1,2+1,2 \mathrm{~S}_{\mathrm{DS}}\right) \mathrm{SiDL}_{-}(1 \rho) \mathrm{Eq}_{\mathrm{x}}+(0,3 \rho) \mathrm{Eq}_{\mathrm{y}}$ \\
\hline 19 & $\left(1,2+1,2 \mathrm{~S}_{\mathrm{DS}}\right) \mathrm{DL}+\left(1,2+1,2 \mathrm{~S}_{\mathrm{DS}}\right) \mathrm{SiDL}-(1 \rho) \mathrm{Eq}_{\mathrm{x}}-(0,3 \rho) \mathrm{Eq}_{\mathrm{y}}$ \\
\hline 20 & ENVELOPE \\
\hline
\end{tabular}

\subsection{Faktor Keutamaan dan Kategori Risiko Bangunan}

Berdasarkan SNI 1726-2012, jenis pemanfaatan bangunan gedung untuk fungsi perhotelan mempunyai kategori risiko III dengan faktor keutamaan gempa $\left(I_{e}\right)$ adalah 1,25.

\subsection{Pemilihan Sistem Struktur}

Penelitian ini menggunakan sistem struktur rangka beton bertulang pemikul momen khusus (SRPMK) dengan koefisien modifikasi respon $(R)$ adalah 8. 


\subsection{Data Gempa}

Parameter gempa untuk kategori gempa tinggi dapat diketahui melalui website online (Pusat Penelitian dan Pengembangan Perumahan dan Permukiman (Pusat Litbang Perumahan dan Permukiman), diperoleh data gempa yang dapat dilihat pada Tabel 2. Gambar 1 merupakan respon spectrum untuk tanah sedang di Kota Bandung.

Tabel 2. Data Kegempaan

\begin{tabular}{ll}
\hline Variabel & Nilai \\
\hline$P G A[\mathrm{~g}]$ & 0,577 \\
\hline$S_{S}[\mathrm{~g}]$ & 1,450 \\
\hline$S_{1}[\mathrm{~g}]$ & 0,486 \\
\hline$C_{R S}$ & 0,977 \\
\hline$C_{R 1}$ & 0,905 \\
\hline$F_{P G A}$ & 1,000 \\
\hline$F_{A}$ & 1,000 \\
\hline$F_{V}$ & 1,514 \\
\hline$P S A[\mathrm{~g}]$ & 0,577 \\
\hline$S_{M S}[\mathrm{~g}]$ & 1,450 \\
\hline$S_{M 1}[\mathrm{~g}]$ & 0,736 \\
\hline$S_{D S}[\mathrm{~g}]$ & 0,967 \\
\hline$S_{D 1}[\mathrm{~g}]$ & 0.490 \\
\hline$T_{0}[$ detik $]$ & 0.101 \\
\hline$T_{S}[$ detik] & 0,507 \\
\hline
\end{tabular}

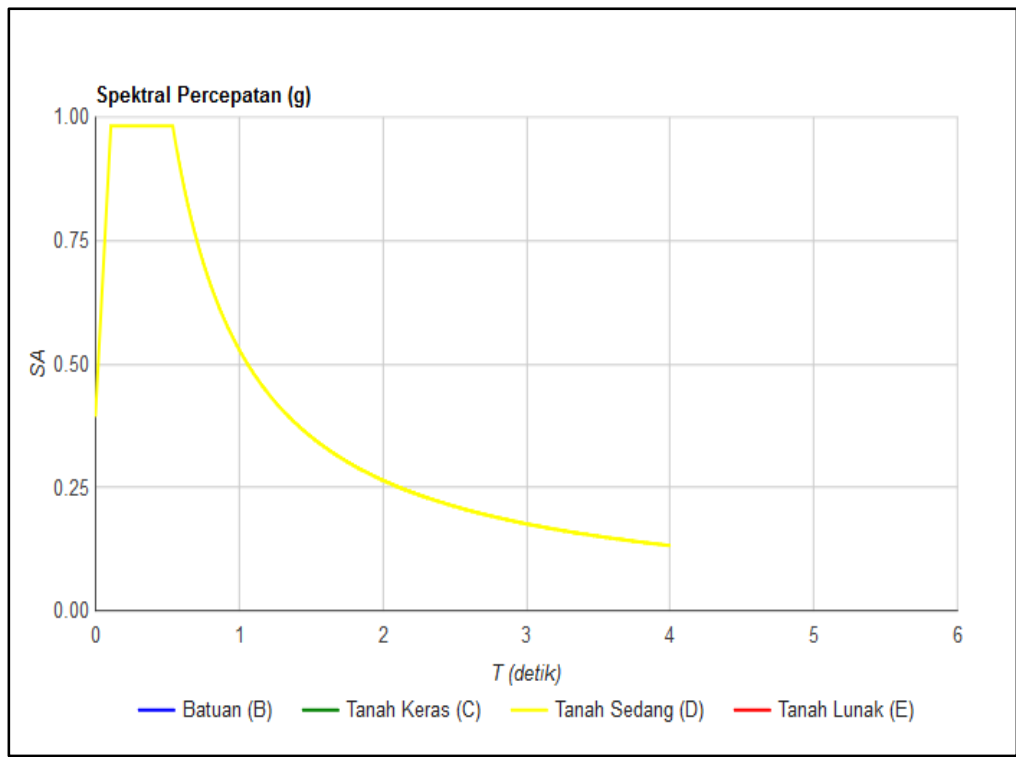

Gambar 1. Respon spektrum untuk tanah sedang (Sumber: puskim.go.id)

\subsection{Periode Fundamental Pendekatan}

Berdasarkan SNI 1726-2012, nilai periode pendekatan batas bawah untuk tipe struktur rangka beton pemikul momen khusus dengan nilai $C_{t}$ adalah 0,0466 dan nilai $x$ adalah 0,9. Persamaan batas bawah dapat dilihat pada Persamaan 1.

$$
T_{\text {a minimum }}=C_{t} * h_{n}^{x}
$$


dengan:

$T_{a \min }=$ periode minimum $[$ detik $]$,

$C_{t} \quad=$ tipe struktur,

$h_{n} \quad=$ ketinggian struktur bangunan [m].

Periode fundamental pendekatan batas atas ditentukan dengan Persamaan 2.

$$
T_{\text {a maksimum }}=C_{u} * T_{\text {a minimum }}
$$

dengan:

$C_{u} \quad=$ parameter percepatan respons spectral desain pada 1 detik.

\subsection{Gaya Geser Seismik}

Berdasarkan SNI 1726:2012 persamaan gaya geser seimik dapat dilihat pada Persamaan 3.

$$
V=C_{s} * W
$$

dengan:

$\begin{array}{ll}V & =\text { gaya geser dasar }[\mathrm{kN}], \\ C_{S} & =\text { koefisien respons seismik, } \\ W & =\text { berat seismik efektif [kN]. }\end{array}$

\subsection{Simpangan Antar Lantai}

Nilai simpangan antar lantai izin harus lebih besar dari selisih defleksi terbesar antar lantai. Persamaan defleksi pusat massa dapat dilihat pada Persamaan 4.

$$
\delta_{x}=\frac{C_{d} * \delta_{x e}}{I_{e}}
$$

dengan:

$\delta_{x} \quad=$ simpangan antar lantai $[\mathrm{mm}]$,

$C_{d} \quad=$ faktor pembesaran defleksi,

$\delta_{x e} \quad=$ defleksi maksimum pada lokasi lantai yang ditinjau [mm],

$I_{e} \quad=$ faktor keutamaan struktur.

Persamaan simpangan antar tingkat izin didasarkan pada kategori risiko dan ketinggian setiap tingkat $\left(h_{s x}\right)$ dengan kategori risiko II, dapat dilihat pada Persamaan 5.

$$
\Delta_{a}=0,025 * h_{s x}
$$

dengan:

$\Delta_{a} \quad=$ simpangan izin [mm],

$h_{s x} \quad=$ ketinggian setiap lantai [mm].

\subsection{Analisis Statik Beban Dorong}

Analisis Statik Beban Dorong (pushover) adalah suatu analisis statik non-linear, yang dalam analisisnya pengaruh gempa rencana terhadap struktur bangunan gedung dianggap sebagai beban statik pada pusat massa masing-masing lantai, yang nilainya ditingkatkan secara berangsur-angsur sampai melampaui pembebanan sehingga menyebabkan terjadinya pelelehan (sendi plastis) pertama di dalam struktur bangunan gedung, kemudian dengan peningkatan beban lebih lanjut mengalami perubahan bentuk pasca-elastik yang besar 
sampai mencapai target peralihan yang diharapkan atau sampai mencapai kondisi plastis (Pranata, Y. A., Simanta, D., 2006).

\subsection{Kurva Kapasitas}

Kurva kapasitas hasil dari analisis statik beban dorong menunjukkan hubungan antara gaya geser dasar dan perpindahan atap akibat beban lateral yang diberikan pada struktur.

\subsection{Titik Kinerja}

Titik kinerja merupakan titik pertemuan kurva demand dengan kurva kapasitas yang digunakan untuk memeriksa apakah komponen structural dan non-struktural tidak melebihi batas kerusakan yang diizinkan.

\subsection{Tingkat Kinerja}

Tingkat kinerja struktur bangunan akibat gempat rencana adalah Life Safety, yaitu walaupun struktur bangunan mengalami tingkat kerusakan yang cukup parah namun keselamatan penghuni tetap terjaga karena struktur bangunan tidak sampai runtuh.

\subsection{Penelitian Terdahulu}

Hasil analisis Ismail (2012), diperoleh bahwa perpindahan lantai dapat direduksi hingga $30 \%$. Penggunaan kontrol base isolation menunjukan struktur dengan base isolation dapat mereduksi gaya gempa yang terjadi pada struktur atas sebesar $47 \%$ dan penggunaan sistem ini dapat memperkecil dimensi komponen struktur. Waktu getar alami yang terjadi diperoleh perpanjangan periode sebesar 2,1 kali lipat dari yang tidak memakai base isolation.

\section{METODE PENELITIAN}

Bagan alir dari penelitian ini dapat dilihat pada Gambar 2.
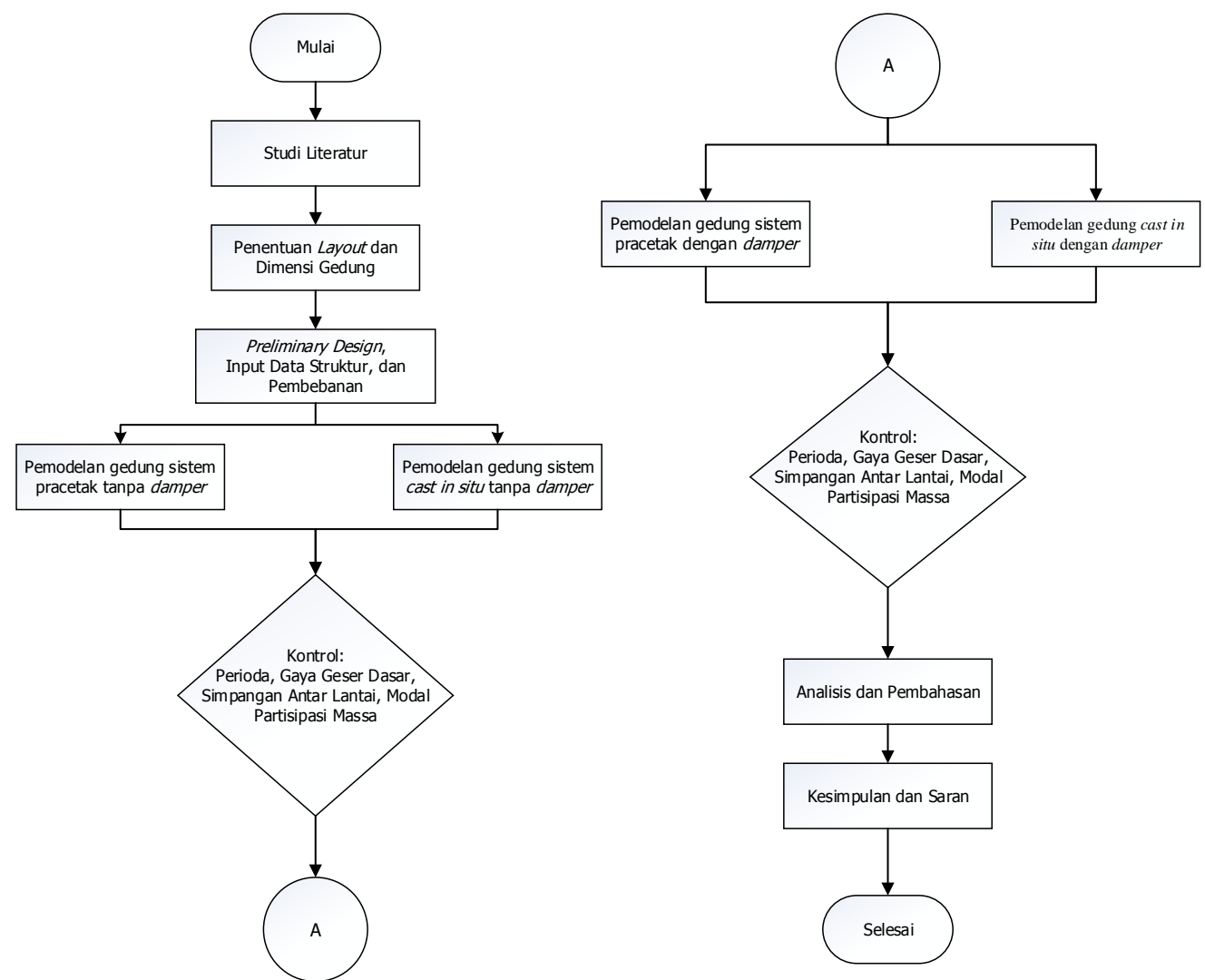

Gambar 2. Bagan alir penelitian

RekaRacana: Jurnal Teknik Sipil - 55 


\section{DESAIN DAN PEMODELAN}

Dalam penelitian ini, pemodelan dengan 4 kasus struktur bangunan yaitu struktur beton cast in situ dengan dan tanpa isolator dan beton pracetak dengan dan tanpa isolator dengan kategori desain seismik D. Sistem rangka yang digunakan adalah Sistem Rangka Pemikul Momen Khusus (SRPMK) dengan data bangunan sebagai berikut:

1. Ketinggian bangunan untuk keempat kasus adalah 10 lantai dengan ketinggian pada lantai 1 adalah 4 meter dan lantai 2-10 adalah 3,6 meter.

2. Fungsi bangunan adalah gedung perhotelan dengan ruang pertemuan di dalamnya dan kategori resiko III.

3. Lokasi bangunan yang digunakan dalam penelitian ini adalah wilayah dengan resiko kegempaan tinggi.

4. Nilai kekakuan untuk struktur beton cast in situ adalah 1 dan nilai kekakuan struktur beton pracetak adalah 0,75 .

Model dan denah struktur bangunan yang digunakan dalam penelitian ini dapat dilihat pada

\section{Gambar 3.}
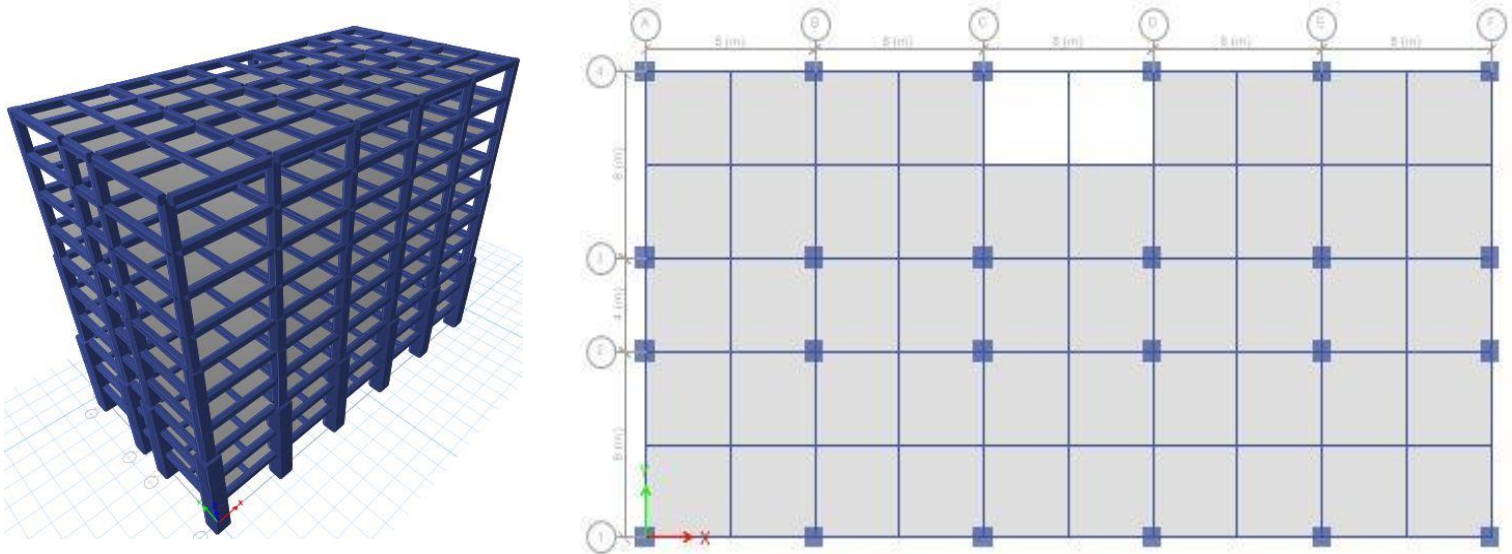

Gambar 3. Pemodelan struktur 3D dan denah bangunan

Hasil analisis pada struktur beton cast in situ dan beton pracetak didapatkan data yang dapat dilihat pada Tabel 3.

Tabel 3. Dimensi Balok, Kolom, dan Pelat

\begin{tabular}{|c|c|c|c|c|c|c|c|c|}
\hline \multirow{5}{*}{$\begin{array}{c}\text { Tanpa Base } \\
\text { Isolator }\end{array}$} & \multicolumn{3}{|c|}{ Balok } & \multicolumn{3}{|c|}{ Kolom } & \multicolumn{2}{|c|}{ Pelat } \\
\hline & Nama & $b[\mathrm{~mm}]$ & $\begin{array}{c}h \\
{[\mathrm{~mm}]}\end{array}$ & Nama & $b[\mathrm{~mm}]$ & $\begin{array}{c}h \\
{[\mathrm{~mm}]}\end{array}$ & Nama & $t[\mathrm{~mm}]$ \\
\hline & B-I & 400 & 600 & KLt1-3 & 700 & 700 & \multirow{3}{*}{$\begin{array}{l}\text { Pelat } \\
\text { Lantai }\end{array}$} & \multirow{3}{*}{120} \\
\hline & B-A & 250 & 400 & KLt4-6 & 550 & 550 & & \\
\hline & & & & KLt7-10 & 250 & 250 & & \\
\hline \multirow{5}{*}{$\begin{array}{c}\text { Dengan Base } \\
\text { Isolator }\end{array}$} & \multicolumn{3}{|c|}{ Balok } & \multicolumn{3}{|c|}{ Kolom } & \multicolumn{2}{|c|}{ Pelat } \\
\hline & Nama & $b[\mathrm{~mm}]$ & $\begin{array}{c}h \\
{[\mathrm{~mm}]}\end{array}$ & Nama & $\begin{array}{c}b \\
{[\mathrm{~mm}]}\end{array}$ & $\begin{array}{c}h \\
{[\mathrm{~mm}]}\end{array}$ & Nama & $t[\mathrm{~mm}]$ \\
\hline & B-I & 400 & 600 & KLt1-3 & 650 & 650 & \multirow{3}{*}{$\begin{array}{l}\text { Pelat } \\
\text { Lantai }\end{array}$} & \multirow{3}{*}{120} \\
\hline & B-A & 250 & 400 & KL4-6 & 500 & 500 & & \\
\hline & & & & KLt7-19 & 200 & 200 & & \\
\hline
\end{tabular}

Berdasarkan hasil perhitungan yang dilakukan dengan menggunakan step design, maka didapat dimensi properti high damping rubber bearing yang telah didesain yang dapat dilihat pada Tabel 4. 
Tabel 4. Tipe dan Spesifikasi Base Isolator yang Digunakan

\begin{tabular}{|c|c|c|c|}
\hline Data & & Satuan & HDRB \\
\hline Diameter bearing & D & $\mathrm{mm}$ & 600 \\
\hline Shear modulus & $\boldsymbol{G}$ & $\mathrm{N} / \mathrm{mm}^{2}$ & 0,392 \\
\hline Tebal rubber layer & $T$ & $\mathrm{~mm}$ & 4 \\
\hline Jumlah rubber layer & $n r$ & & 50 \\
\hline Tebal total rubber & $t r$ & $\mathrm{~mm}$ & 200 \\
\hline Tebal shims & $t s$ & $\mathrm{~mm}$ & 3,1 \\
\hline Jumlah shims & ns & & 49 \\
\hline Tinggi & $\boldsymbol{H}$ & $\mathrm{mm}$ & 407,9 \\
\hline Berat & $W$ & $\mathrm{kN}$ & 6,5 \\
\hline Massa & $M$ & ton & 0,66 \\
\hline
\end{tabular}

\section{PEMBAHASAN}

Dari hasil analisis diperoleh periode struktur yang menggunakan base isolator lebih besar daripada yang tidak menggunakan base isolator. Dengan adanya base isolator, maka gaya gempa yang mengenai struktur akan terlebih dahulu bekerja pada isolator kemudian baru diteruskan ke struktur atas dan menyebabkan gaya gempa yang bekerja pada bangunan akan menjadi lebih kecil. Peningkatan periode struktur pada beton cast in situ mencapai 2 kali lebih besar dari bangunan tanpa base isolator sedangkan pada beton pracetak mencapai 2,3 kali lebih besar seperti yang bisa dilihat pada Gambar 4. Periode yang diperoleh dari pemodelan dapat dilihat pada Tabel 5.

Tabel 5. Periode Struktur Beton Cast in Situ dan Beton Pracetak

\begin{tabular}{ccccc} 
& \multicolumn{2}{c}{ Tanpa Isolator } & \multicolumn{2}{c}{ Dengan Isolator } \\
\cline { 2 - 5 } Mode & Cast In Situ & Pracetak & Cast In Situ & Pracetak \\
\cline { 2 - 5 } & $\begin{array}{c}\boldsymbol{T} \\
\text { [detik] }\end{array}$ & $\begin{array}{c}\boldsymbol{T} \\
\text { [detik] }\end{array}$ & $\begin{array}{c}\boldsymbol{T} \\
\text { [detik] }\end{array}$ & $\begin{array}{c}\boldsymbol{T} \\
\text { [detik] }\end{array}$ \\
\hline 1 & 1,294 & 2,185 & 2,789 & 4,522 \\
\hline 2 & 1,224 & 2,052 & 2,643 & 4,215 \\
\hline 3 & 1,073 & 1,7 & 2,297 & 3,701 \\
\hline
\end{tabular}

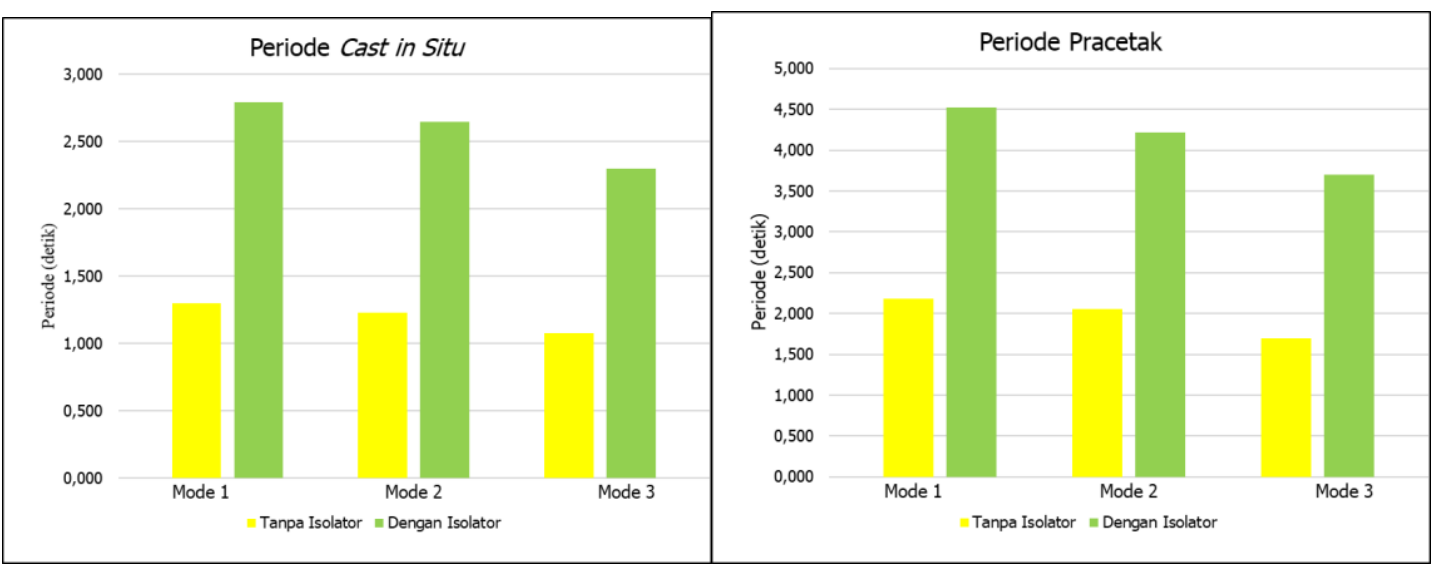

Gambar 4. Perbandingan periode dengan dan tanpa base isolator

Tabel 6. Gaya Geser Dasar Beton Cast in Situ dan Beton Pracetak

\begin{tabular}{|c|c|c|c|c|}
\hline \multirow{3}{*}{ Jenis Struktur } & \multicolumn{4}{|c|}{$\begin{array}{l}\text { Gaya Geser Dasar dalam Arah Sumbu X dan Arah Sumbu } \mathbf{Y} \\
\qquad V[k N]\end{array}$} \\
\hline & \multicolumn{2}{|c|}{ Tanpa Isolator } & \multicolumn{2}{|c|}{ Dengan Isolator } \\
\hline & $F X$ & $F Y$ & $F X$ & $F Y$ \\
\hline Cast In situ & $3.410,3637$ & $3.514,6897$ & $1.908,0706$ & $1.969,4604$ \\
\hline Pracetak & $2.868,2859$ & $2.859,0443$ & $1.257,3104$ & $1.232,3607$ \\
\hline
\end{tabular}


Hasil analisis perbandingan nilai base shear dengan dan tanpa base isolator didapatkan nilai rata-rata reduksi gaya geser pada arah X mencapai 44,05\% untuk beton cast in situ dan $56,16 \%$ untuk beton pracetak, sedangkan gaya geser pada arah $Y$ mencapai $43,96 \%$ untuk beton cast in situ dan 56,89\% untuk beton pracetak. Tabel 6 menunjukkan gaya geser dasar beton cast in situ dan beton pracetak.

Pada Tabel 7 berikut menunjukkan nilai simpangan antar lantai dari keempat kasus untuk arah UX dan arah UY. Berdasarkan Tabel 7 di bawah diketahui bahwa nilai simpangan antar lantai memenuhi persyaratan yaitu simpangan antar lantai tidak lebih besar dari simpangan yang diizinkan sebesar $80 \mathrm{~mm}$ untuk semua kasus pemodelan struktur.

Tabel 7. Simpangan Antar Lantai Beton Cast in Situ dan Beton Pracetak

\begin{tabular}{|c|c|c|c|c|c|c|c|}
\hline \multirow{2}{*}{ Tipe } & \multicolumn{4}{|c|}{$\begin{array}{c}\text { Simpangan } \\
\text { AntarLantaiMaks }[\mathrm{mm}]\end{array}$} & \multirow{2}{*}{$\begin{array}{c}\text { Simpangan } \\
\text { Izin } \\
{[\mathrm{mm}]}\end{array}$} & \multicolumn{2}{|c|}{ Keterangan } \\
\hline & Arah $X$ & Lokasi & Arah $Y$ & Lokasi & & Arah $X$ & Arah $Y$ \\
\hline $\begin{array}{l}\text { Cast in Situ tanpa } \\
\text { Isolator }\end{array}$ & 57,816 & Lantai 3 & 54,177 & Lantai 4 & 80 & OK & OK \\
\hline $\begin{array}{l}\text { Pracetaktanpa } \\
\text { Isolator }\end{array}$ & 57,917 & Lantai 3 & 58,331 & Lantai 4 & 80 & OK & OK \\
\hline $\begin{array}{l}\text { Cast in Situ dengan } \\
\text { Isolator }\end{array}$ & 58,252 & Lantai 3 & 60,069 & Lantai 4 & 80 & OK & OK \\
\hline $\begin{array}{l}\text { Pracetakdengan } \\
\text { Isolator }\end{array}$ & 59,035 & Lantai 3 & 63,228 & Lantai 3 & 80 & OK & OK \\
\hline
\end{tabular}

Tabel 8 menunjukkan modal partisipasi massa untuk keempat kasus arah UX dan arah UY. Seperti yang terlihat pada Tabel 8 bahwa dengan penggunaan base isolator membutuhkan waktu yang lebih singkat untuk mencapai faktor partisipasi modal yang diinginkan sesuai peraturan yaitu minimal $90 \%$.

Tabel 8. Modal Partisipasi Massa Beton Cast in Situ dan Beton Pracetak

\begin{tabular}{ccccccccc}
\hline & \multicolumn{4}{c}{ Cast in Situ } & \multicolumn{5}{c}{ Pracetak } \\
\hline \multirow{2}{*}{ Mode } & \multicolumn{1}{c}{ Tanpa Isolator } & \multicolumn{2}{c}{ Dengan Isolator } & \multicolumn{2}{c}{ Tanpa Isolator } & \multicolumn{2}{c}{ Dengan Isolator } \\
\cline { 2 - 10 } & UX [\%] & UY [\%] & UX [\%] & UY [\%] & UX [\%] & UY [\%] & UX [\%] & UY [\%] \\
\hline 1 & 60,15 & 0,00 & 93,27 & 0,00 & 49,54 & 0,00 & 80,36 & 0,00 \\
\hline 2 & 0,00 & 60,62 & 0,00 & 94,06 & 0,00 & 50,11 & 0,00 & 81,14 \\
\hline 3 & 0,00 & 0,00 & 0,00 & 0,00 & 0,00 & 0,00 & 0,00 & 0,00 \\
\hline 4 & 14,41 & 0,00 & 5,56 & 0,00 & 18,47 & 0,00 & 13,23 & 0,00 \\
\hline 5 & 0,00 & 14,55 & 0,00 & 5,06 & 0,00 & 18,06 & 0,00 & 13,28 \\
\hline 6 & 0,00 & 0,00 & 0,00 & 0,00 & 0,00 & 0,00 & 0,00 & 0,00 \\
\hline 7 & 8,74 & 0,00 & 0,84 & 0,00 & 12,93 & 0,00 & 5,98 & 0,00 \\
\hline 8 & 0,00 & 8,41 & 0,00 & 0,7 & 0,00 & 12,85 & 0,00 & 5,17 \\
\hline 9 & 0,00 & 0,00 & 0,00 & 0,00 & 0,00 & 0,00 & 0,00 & 0,00 \\
\hline 10 & 3,92 & 0,00 & 0,32 & 0,00 & 5,4 & 0,00 & 0,37 & 0,00 \\
\hline 11 & 0,00 & 3,87 & 0,00 & 0,07 & 0,00 & 5,4 & 0,00 & 0,35 \\
\hline 12 & 0,00 & 0,00 & 0,00 & 0,00 & 0,00 & 0,00 & 0,00 & 0,00 \\
\hline 13 & 2,61 & 0,00 & - & - & 2,92 & 0,00 & - & - \\
\hline 14 & 0,00 & 2,58 & - & - & 0,00 & 2,94 & - & - \\
\hline 15 & 0,00 & 0,00 & - & - & 0,00 & 0,00 & - & - \\
\hline 16 & 2,3 & 0,00 & - & - & 2,51 & 0,00 & - & - \\
\hline 17 & 0,00 & 1,63 & - & - & 0,00 & 2,52 & - & - \\
\hline Jumlah & 92,31 & 91,66 & 99,99 & 99,89 & 91,77 & 91,88 & 99,94 & 99,94 \\
\hline
\end{tabular}



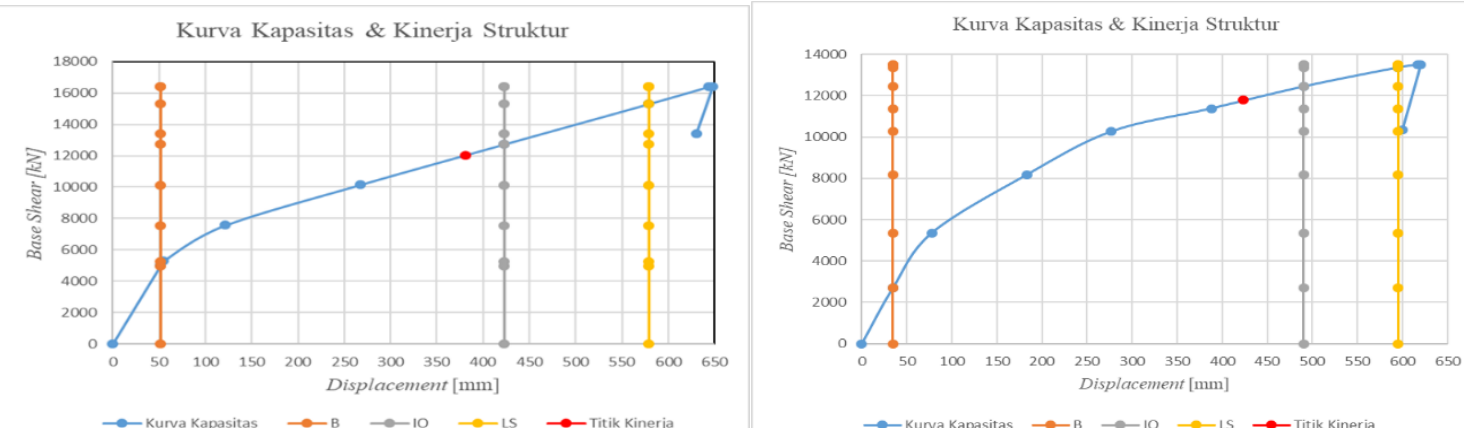

Gambar 5. Kurva Kapasitas dan Kinerja Struktu
Cast in Situ tanpa Base IsolatorArah UX

Gambar 6. Kurva Kapasitas dan Kinerja Struktur Cast in Situ tanpa Base IsolatorArah UX Cast in Situ tanpa Base IsolatorArah UY
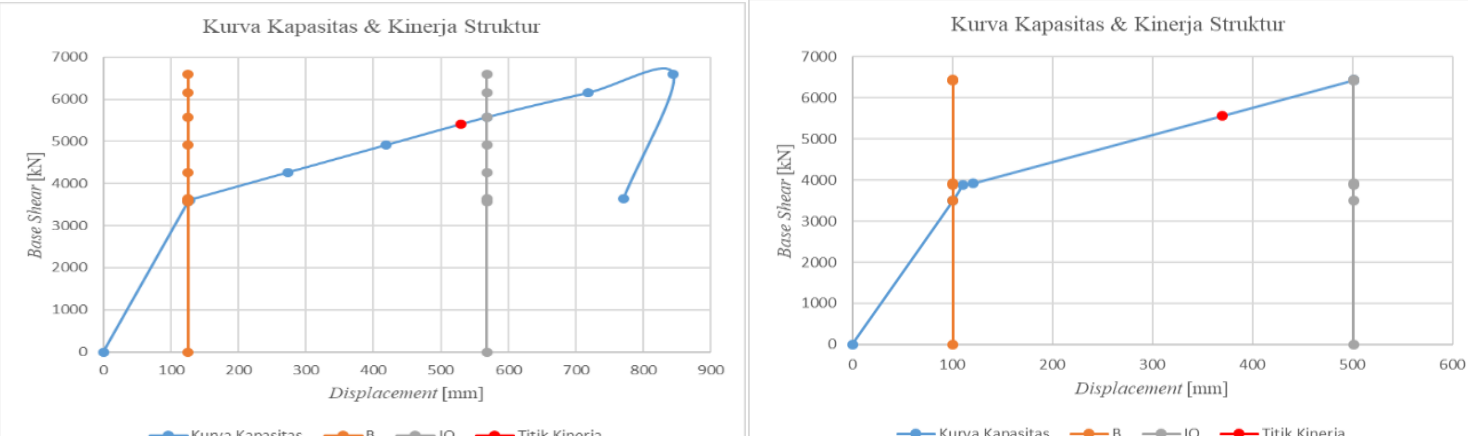

Gambar 7. Kurva Kapasitas dan Kinerja Struktur Gambar 8. Kurva Kapasitas dan Kinerja Struktur Pracetaktanpa Base IsolatorArah UX

Pracetaktanpa Base IsolatorArah UY
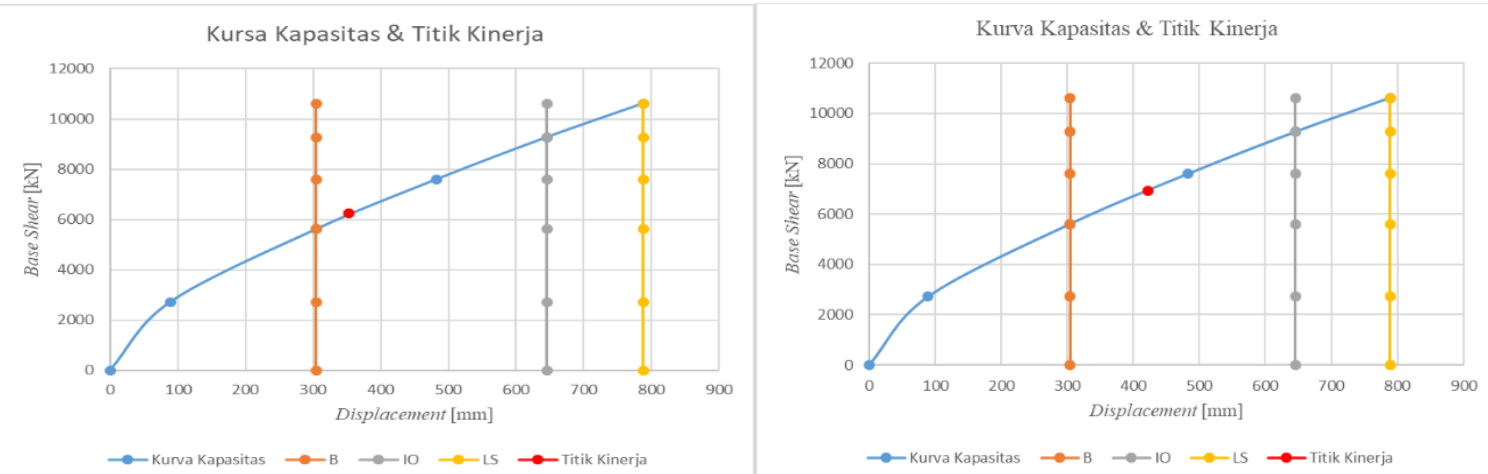

Gambar 9. Kurva Kapasitas dan Kinerja Struktur Gambar 10. Kurva Kapasitas dan Kinerja Struktur Cast in Situ dengan Base IsolatorArah UX

Cast in Situ dengan Base IsolatorArah UY

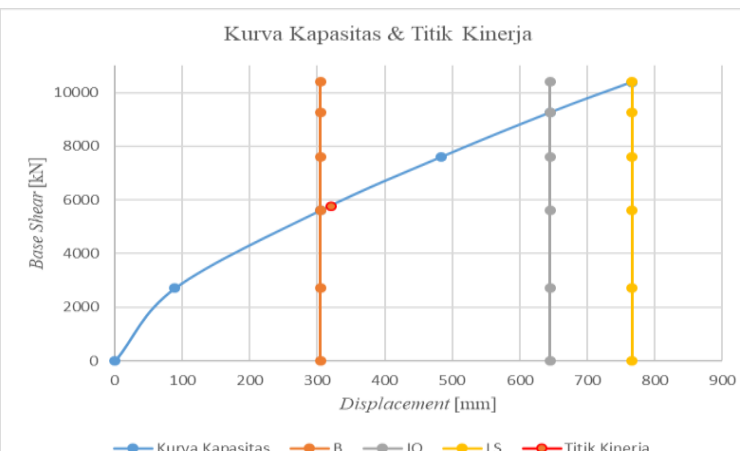

Gambar 11. Kurva Kapasitas dan Kinerja Struktur Pracetakdengan Base IsolatorArah UX

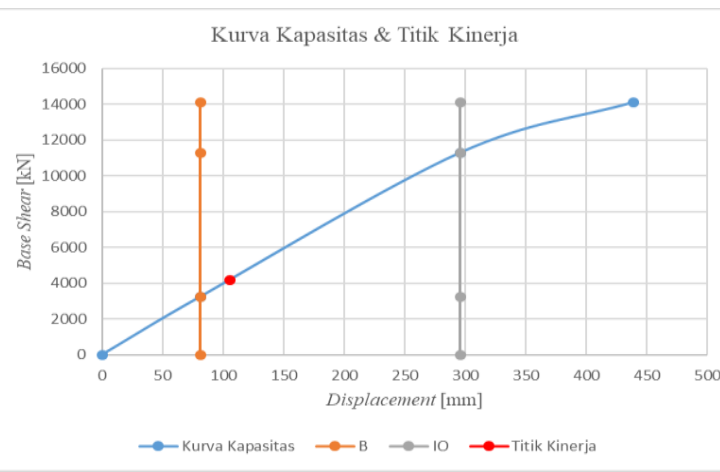

Gambar 12. Kurva Kapasitas dan Kinerja Struktur Pracetakdengan Base IsolatorArah UY 
Dari Gambar 5, Gambar 6, Gambar 7, Gambar 8, Gambar 9,Gambar 10, Gambar 11, dan Gambar 12 di atas didapatkan bahwa kinerja struktur pada saat kondisi Performance Point, semua tipe struktur berada pada level yang sama yaitu berada pada kinerja B (Operational) to IO (Immediate Occupancy) yaitu kondisi dimana ketika terjadi gempa bangunan tidak ada kerusakan yang berarti pada komponen struktural. Kekuatan dan kekakuan gedung hampir sama dengan kondisi sebelum dilanda gempa. Pada komponen non-struktural, peralatan, dan isi gedung umumnya masih aman, tetapi secara operasional tidak dapat bekerja karena kegagalan mekanik atau kurangnya utilitas.

\section{KESIMPULAN}

Berdasarkan perhitungan dan analisis untuk keempat kasus yaitu struktur beton cast in situ dengan dan tanpa base isolator dan juga struktur beton pracetak dengan dan tanpa base isolator, maka dapat diambil kesimpulan sebagai berikut:

1. Berdasarkan analisis yang telah dilakukan, periode getar alami struktur antara kedua struktur beton semakin membesar dikarenakan penggunaan base isolator, untuk struktur beton cast in situ terjadi pembesaran nilai periode mencapai 2 kali lebih besar dari bangunan tanpa base isolator sedangkan pada beton pracetak mencapai 2,3 kali lebih besar dari bangunan tanpa base isolator. Hal ini menyebabkan gaya gempa yang bekerja pada bangunan akan menjadi lebih kecil.

2. Berdasarkan perhitungan yang dilakukan diperoleh bahwa penggunaan base isolator dapat mereduksi gaya geser dasar yang terjadi pada bangunan. Hasil analisis perbandingan base shear dengan dan tanpa base isolator didapatkan nilai rata-rata reduksi gaya geser pada arah $X$ mencapai $44,05 \%$ untuk beton cast in situ dan $56,16 \%$ untuk beton pracetak, sedangkan reduksi gaya geser pada arah $Y$ mencapai 43,96\% untuk beton cast in situ dan $56,89 \%$ untuk beton pracetak.

3. Untuk analisis dan perhitungan simpangan antar lantai, didapatkan bahwa simpangan antar lantai maksimum terbesar adalah beton pracetak yang menggunakan base isolator dengan nilai simpangan $63,228 \mathrm{~mm}$, sedangkan simpangan antar lantai izinnya adalah $72 \mathrm{~mm}$, maka dari itu simpangan antar lantai dari keempat kasus tersebut sudah memenuhi persyaratan yang telah ditentukan.

4. Berdasarkan analisis yang dilakukan, pada pemodelan gedung cast in situ dan pracetak tanpa base isolator diperoleh jumlah partisipasi massa untuk arah UX dan arah UY telah mencapai minimal $90 \%$ saat mode ke-17, sedangkan pada pemodelan gedung cast in situ dan pracetak dengan menggunakan base isolator diperoleh jumlah partisipasi massa untuk arah UX dan arah UY telah mencapai minimal $90 \%$ saat mode ke-12. Ini disebabkan karena dengan panggunaan base isolator akan membutuhkan waktu yang lebih singkat untuk mencapai faktor partisipasi modal yang diinginkan sesuai peraturan yaitu minimal $90 \%$.

5. Berdasarkan analisis non-linier pushover didapatkan bahwa semua tipe struktur berada pada level yang sama yaitu berada pada kinerja B (Operational) to IO (Immediate Occupancy) yaitu kondisi dimana ketika terjadi gempa, bangunan tidak ada kerusakan yang berarti pada komponen struktural. Kekuatan dan kekakuan gedung hampir sama dengan kondisi sebelum dilanda gempa. Pada komponen non-struktural, peralatan, dan isi gedung umumnya masih aman, tetapi secara operasional tidak dapat bekerja karena kegagalan mekanik atau kurangnya utilitas.

6. Secara keseluruhan dapat disimpulkan bahwa respon dan kinerja struktur pada beton pracetak yang menggunakan base isolator dinilai lebih efektif dibandingkan dengan beton cast in situ. 


\section{SARAN}

Setelah melakukan penelitian ini, penulis memberikan saran yang mungkin bermanfaat bagi pengembangan penelitian ini ditahap selanjutnya.

1. Pada penelitian selanjutnya, dilakukan analisis penggunaan kombinasi base isolator dalam beberapa model struktur (tidak beraturan, jumlah lantai, jenis base isolator, dan variasi sambungan pada beton pracetak), agar penerapan base isolator pada tiap model bangunan dapat diketahui lebih detail.

2. Untuk lebih menyesuaikan penggunaan sistem base isolation di Indonesia, perlunya segera dibuat standar nasional yang dapat menyesuaikan kondisi daerah Indonesia dengan zona gempa yang ada.

\section{DAFTAR RUJUKAN}

Badan Standardisasi Nasional. (2012). SNI 1726:2012 tentang Tata Cara Perencanaan Ketahanan Gempa untuk Struktur Bangunan Gedung dan Non Gedung. Jakarta: Badan Standardisasi Nasional.

Badan Standardisasi Nasional. (2013). SNI 1727:2013 tentang Beban Minimum untuk Perancangan Bangunan Gedung dan Struktur Lain. Jakarta: Badan Standardisasi Nasional.

Ismail, Anas. (2012). Pengaruh Penggunaan Seismic Base Isolation System Terhadap Respons Struktur Gedung Hotel Ibis Padang. Jurnal Rekayasa Sipil, 8(1), 50-62.

Myes, R. L. \& Naeim, F. (2001). Chapter 14: Design of Structures with Seismic Isolation. Boston: Kluwer Academic Pub.

Naeim, F., \& Kelly, J.M. (1999). Design Of Seismic Isolated Structures: From Theory To Practice. New York: John Wiley \& Sons, Inc.

Pranata, Y. A., Simanta, D. (2006). Studi Analisis Beban Dorong untuk Gedung Beton Bertulang. Jurnal Teknik Sipil, 2(1), 235.

Pusat Penelitian dan Pengembangan Permukiman. (2018, November 26). Peta Google. Diambil kembali dari Desain Spektra Indonesia: http://puskim.pu.go.id/Aplikasi/desain_spektra_indonesia_2011/result/?t=eyJsb2Nhd GlvbiI6eyJsYXQiOiItNi44ODkxNDE4OTA5OTg4NzUiLCJsbmciOiIXMDcuNTgxOTcwMjE0 ODQzNzUifSwicmVzdWx0Ijp7IkIiOnsicGdhIjowLjU5MDUzOTU5MTAwNzkzLCJwc2EiOj AuNTkxLCJzcyI6MS400TcsInMxIjowLjU 